\title{
A LIST of the AMPHIBIANS and REPTILES of
}

SAN DIEGO COUNTY, CALIFORNIA

By L. M. KlaÚber

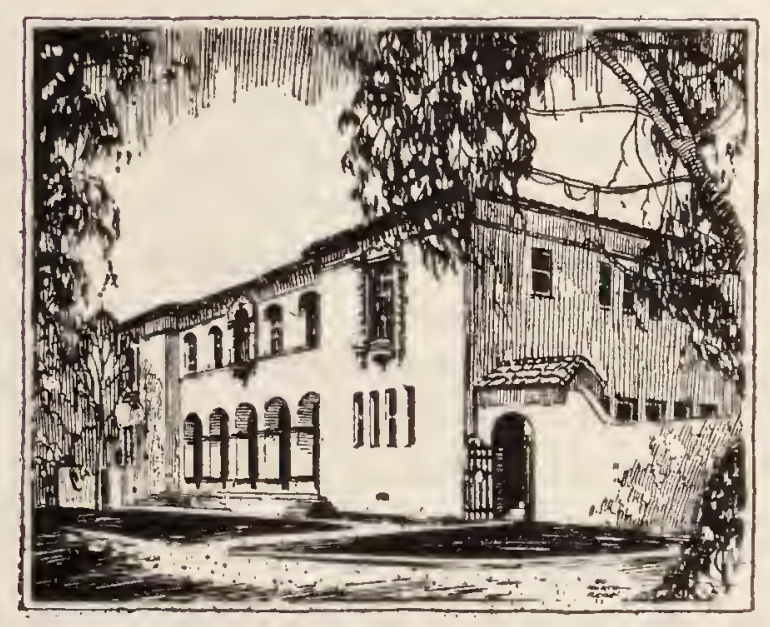

ZOOLOGICAL SOCIETY OF SAN DIEGO

Bulletin No. 4

July 1, 1928 


\title{
A LIST OF THE AMPHIBIANS AND REPTILES \\ of \\ SAN DIEGO COUNTY, CALIFORNIA
}

\author{
by L. M. KLAUBER
}

A. NEWTS AND SAIAMANDERS

1. Pacific Coast Newt Triturus torosus (Eschscholtz)

Common in Boulder and Cedar Creeks.

2. Southern Slender Salamander Batrachoseps attenuatus leucopus (Dunn)

Well distributed from the ocean to the mountains. Common in city gardens under stones and boards.

3. Yellow-spotted Salamander Ensatina croceater (Cope)

Moderately rare. Recorded from several mountain localities in leaf mold or under fallen logs.

4. Arboreal Salamander Aneides lugubris lugubris (Hallowell) Rare. Recorded from several coast and foothill points.

B. FROGS AND TOADS

1. Western Spadefoot Toad Scaphiopus hammondii Baird Has been taken in a number of localities from the ocean to the mountains. Usually out after rains.

2. California Toad Bufo boreas halophilus (Baird and Girard)

Common from the ocean to the mountains. The adults are active only at night as is the case with most toads.

3. Arroyo Toad Bufo cognatus californicus Camp Moderately common in inland valleys and foothills.

4. Spotted Toad Bufo punctatus Baird and Girard Rare in desert slope oases.

5. Canyon Tree-frog Hyla arenicolor Cope

Moderately common in rocky canyons from the foothills to the desert. Usually found on boulder faces.

6. Pacific Tree-frog Hyla regilla Baird and Girard Common from the ocean to the desert in moist localities.

7. California Red-legged Frog Rana aurora draytonii (Baird and Girard)

Moderately common in streams and ponds from the ocean to the mountains.

C. LIZARDS

1. Tubercular Gecko Phyllodactylus tuberculosus Wiegmann Moderately rare in rocky areas on the desert slope. Nocturnal.

2. Banded Gecko Coleonyx variegatus (Baird) Occasional from the ocean to the desert. Nocturnal.

3. Northern Crested Lizard Dipsosaurus dorsalis dorsalis (Baird and Girard)

Common on the desert in sandy areas. 
4. Western Collared Lizard Crotaphytus collaris baileyi (Stejneger)

Moderately common on the tumbled boulders of the desert slope.

5. Leopard Lizard Crotaphytus wislizenii Baird and Girard

Moderately common on the desert slope and desert in sandy areas. Occasional in the western foothills.

6. Chuckwalla Sauromalus obesus (Baird)

Moderately rare on boulder strewn desert slopes.

7. Desert Gridiron-tailed Lizard Callisaurus ventralis gabbii Cope Quite common from the mountains to the desert. A lizard of the sandy washes.

8. Long-tailed Swift Uta graciosa (Hallowell)

Moderately rare on the desert, usually on cactus or brush.

9. Mearn's Rock Lizard Uta mearnsi Stejneger

Common on the rough granite boulders of the desert slope.

10. Small-scaled Swift Uta microscutata Van Denburgh

Rather rare in rocky areas along the Mexican border.

11. California Brown-shouldered Lizard Uta stansburiana hesperis Richardson

Exceedingly common from the ocean shore to the mountains, alike in rocky areas, chaparral or open fields.

12. Desert Brown-shouldered Lizard Uta stansburiana stejnegeri Schmidt

Common on the desert slope and desert.

13. Southern Mountain Swift Sceloporus graciosus vandenburgianus (Cope)

Moderately common on Laguna, Cuyamaca and Palomar Mountains.

14. Desert Scaly Lizard Sceloporus magister Hallowell

Moderately rare on the desert usually in the branches of shrubs.

15. Western Fence Lizard Sceloporus occidentalis biseriatus (Hallowell)

Exceedingly common from the ocean to the desert slope on rocks, fences or trees.

16. Dusky Scaly Lizard Sceloporus orcutti Stejneger

Common among boulders in the foothills on both slopes.

17. Southern California Horned Toad Phrynosoma blainvillii blainvillii (Gray)

Common from the ocean to the mountains in fields or chaparral.

18. Flat-tailed Horned Toad Phrynosoma m'callii (Hallowell)

Moderately rare in sandy areas on the desert.

19. Desert Horned Toad Phrynosoma platyrhinos Girard

Moderately common on the desert slope and desert.

20. San Diegan Alligator Lizard Gerrhonotus scincicauda webbii (Baird) 
Common from the ocean to the mountains, especially about human habitations.

21. Silvery Footless Lizard Anniella pulchra Gray

Subterranean. Moderately common throughout the county in sandy soil.

22. Spotted Night Lizard Xantusia henshawi Stejneger

Common under rock flakes on the foothills of both slopes. Nocturnal.

23. Desert Night Lizard Xantusia vigilis Baird

Rare on the desert slope and desert. Nocturnal.

24. California Orange-throated Lizard Verticaria hyperythra beldingi (Stejneger)

Moderately rare from the ocean to the mountains usually in brush.

25. Desert Whiptail Lizard Cnemidophorus tessellatus tessellatus (Say)

Common on the desert in sandy rockstrewn areas.

Common on the desert in sand rockstrewn areas.

26. San Diegan Whiptail Lizard Cnemidophorus tessellatus stejnegeri (Van Denburgh)

Moderately common from the ocean to the desert in brushy areas.

27. Western Skink Eumeces skiltonianus (Baird and Girard)

Moderately common from the ocean to the desert slope usually under rocks, leaves or debris.

D. SNAKES

1. Western Worm Snake Siagonodon humilis (Baird and Girard) Subterranean. Rather rare from the ocean to the desert.

2. California Boa Lichanura roseofusca Cope

Moderately common from the ocean to the desert usually in chaparral or amongst boulders.

3. San Diegan Ring-neck Snake Diadophis amabilis similis Blanchard

Moderately common from the ocean to the mountains particularly in gardens or other moist areas.

4. Western Yellow-bellied Racer Coluber constrictor mormon (Baird and Girard)

Rare from the ocean to the desert foothills. A snake of the open fields.

5. Red Racer Masticophis flagellum frenatus (Stejneger)

Moderately common from the ocean to the desert in fields or brush.

6. California Striped Racer Masticophis lateralis (Hallowell)

Common from the ocean to the mountains especially in chaparral.

7. Western Patch-nosed Snake Salvadora grahamiae hexalepis (Cope) 
Moderately rare from the ocean to the desert.

8. Lower California Leaf-nosed Snake Phyllorhynchus decurtatus (Cope)

Rare. Several specimens have been taken in the desert foothills. A nocturnal snake.

9. Western Faded Snake Arizona elegans occidentalis Blanchard Moderately rare from the ocean to the desert. Crepuscular.

10. San Diegan Gopher Snake Pituophis catenifer annectens (Baird and Girard)

Very common from the ocean to the desert foothills. The most beneficial of our snakes.

11. California King Snake Lampropeltis californiae californiae (Blainville)

Moderately common from the ocean to the desert foothills.

12. Boyle's King Snake Lampropeltis getulus boylii (Baird and Girard)

Common from the ocean to the desert.

13. Coral King Snake Lampropeltis multicincta (Yarrow)

Rare in the mountains. The most brilliantly colored of our local species.

14. Long-nosed Snake Rhinocheilus lecontei Baird and Girard

Moderately common from the ocean to the desert. Crepuscular.

15. Shovel-nosed Ground Snake Sonora occipitalis (Hallowell)

Rather rare on the desert. Nocturnal. Perfers sandy washes.

16. Spotted Night Snake Hypsiglena ochrorhynchus Cope

Moderately rare from the ocean to the desert. Nocturnal. USually taken in rocky sections.

17. Pacific Garter Snake Thamnophis sirtalis infernalis (Blainville)

Several specimens have been taken in the northern section of the county along the rivers.

18. California Garter Snake Thamnophis ordinoides hammondii (Kennicott)

Very common from the ocean to the mountains especially about streams and ponds.

19. Mountain Garter Snake Thamnophis ordinoides elegans (Baird and Girard)

Several specimens have been taken on Laguna Mountain.

20. California Tantilla Tantilla eiseni Stejneger

Rare from the ocean to the desert foothills. A burrowing sake.

21. California Lyre Snake Trimorphodon vandenburghi Klauber

Rare from the ocean to the desert foothills. Nocturnal. Usually taken in rocky areas.

22. Sidewinder Crotalus cerastes Hallowell

Moderately common in the desert. Crepuscular. Sometimes called Horned Rattlesnake. 
23. Red Diamond Rattlesnake Crotalus exsul Garman

Common from the ocean to the desert foothills especially in cactus and amongst boulders. The largest of our local rattlers.

24. Bleached Rattlesnake Crotalus mitchellii (Cope)

Moderately common from the foothills to the desert in rocky areas or chaparral.

25. Pacific Rattlesnake Crotalus oreganus Holbrook

Common from the ocean to the desert in fields, brush or rocks.

E. TORTOISES AND TURTLES

1. Pacific Mud Turtle Clemmys marmorata (Baird and Girard) Moderately rare in streams and ponds.

2. Pacific Green Turtle Chelonia agassizii Bocourt

Occasional in the bay and on the coast.

3. Pacific Leather-back Turtle Dermochelys schlegelii (Garman) One was secured off Pt. Loma 40 years ago.

\section{SPECIES REPOR'TED FROM AREAS CLOSELY ADJACENT TO SAN DIEGO COUNTY}

\section{AA. NEWTS AND SALAMANDERS}

1. Garden Salamander Batrachoseps attenuatus major (Camp) Has been reported from both Riverside and Orange Counties.

BB. FROGS AND TOADS

1. Great Plains Toad Bufo cognatus cognatus (Say)

Has been reported from Brawley and Coachella and may occur in the northeast corner of our County.

2. Sierra Madre Yellow-legged Frog Rana boylii muscosa Camp Has been taken as far south as San Jacinto Mts.

3. Leopard Frog Rana pipiens Schreber

Has been reported from Dixieland, Imperial County.

CC. LIZARDS

1. Oscellated Sand Lizard Uma notada Baird

A desert species found in Imperial County which may be expected within our eastern borders.

2. Striped Scaly Lizard Sceloporus rufidorsum Yarrow

A Lower California species which has been found somewhat north of Ensenada. 
DD. SNAKES

1. Black Whip Snake Masticophis piceus (Cope)

Occurs in Lower California somewhat north of Ensenada.

2. Desert Gopher Snake Pituophis catenifer deserticola Stejneger Common in Imperial Valley and almost certain to occur in northeastern San Diego County.

3. Striped Ground Snake Sonora episcopa (Kennicott)

Not uncommon in Imperial Valley and may be expected in northeastern San Diego County.

4. Banded Burrowing Snake Chilomeniscus cinctus Cope A desert species which has been found in Imperial County.

5. Desert Diamond Rattlesnake Crotalus atrox atrox (Baird and Girard)

Has been taken as far west as Seeley, Imperial County and may occur in northeastern San Diego County.

EE. TORTOISES AND TURTLES

1. Desert Tortoise Gopherus agassizii (Cooper)

Not uncommon in Imperial County and may occur in eastern San Diego County.

2. Pacific Loggerhead Turtle Caretta olivacea (Eschscholtz) May visit our coast.

Note-Rattlesnakes are the only dangerously venomous snakes found in California. Most other snakes are beneficial to agriculture (by their destruction of harmful rodents) and should be protected.

The Zoological Society of San Diego will appreciate donations of live amphibians and reptiles from San Diego County or contiguous areas. Such specimens are not only useful for our exhibits and for scientific study but likewise enable us to secure by exchange specimens from other districts. 


\section{RECEN'T WORKS OF INTEREST \\ IN THE STUDY OF THE \\ HERPETOLOGY OF SAN DIEGO COUNTY}

1925. Blanchard, Frank N.

A Key to the Snakes of the United States, Canada and Lower California. Papers of the Michigan Academy of Science, Arts and Letters, Vol. 4, Part 2, pp. 1-65.

1917. Grinnell, Jos. and Camp, Chas. L.

A Distributional List of the Amphibians and Reptiles of California. University of Calforna Publications in Zoology, Vol. 17, No. 10, pp. 127-298.

1924. Klauber, L. M.

Notes on the Distribution of Snakes in San Diego County, California.

Bull. Zool. Soc. of San Diego, No. 1, pp. 1-23.

1927. Klauber, L. M.

Some Observations on the Rattlesnakes of the Extreme Southwest.

Bull. Antivenin Inst. of America Vol. 1, No. 1, pp. 7-21.

1927. Klauber, L. M.

Notes on the Salamanders of San Diego County, California. Bull.

Zool. Soc. of San Diego, No. 3, pp. 1-4.

1922. Schmidt, Karl Patterson

The Amphibians and Reptiles of Lower California, Bull. Am. Mus.

Nat. Hist. Vol. 46, Art. 11, pp. 607-707.

1923. Stejneger, Leonhard and Barbour, Thomas

A Check List of North American Amphibians and Reptiles. Second Edition, pp. XX-171. Harvard University Press.

1921. Stephens, Frank

An Annoted List of the Amphibians and Reptiles of San Diego

County, California. Trans. San Diego Soc. Nat. Hist. Vol. 3, No. 4, pp. 57-69.

1925. Storer, Tracy I.

A Synopsis of the Amphibia of California. University of Calif. Pubs. in Zool. Vol. 27, pp. 1-342.

1922. Van Denburgh, John

The Reptiles of Western North America. Occas. Papers, Calif. Acad.

Sci. No. 10, Vol. 1, Lizards. Vol. 2, Snakes and Turtles, pp. 1-1028. 